Karol Król

Uniwersytet Rolniczy im. Hugona Koltątaja w Krakowie

\title{
Witryny i aplikacje mobilne w promocji gospodarstw agroturystycznych
}

\section{WEBSITES AND MOBILE APPLICATIONS IN PROMOTION OF AGROTOURISTIC FARMS}

Celem pracy była ocena możliwości oraz stopnia wykorzystania przez gospodarstwa agroturystyczne witryn $i$ aplikacji mobilnych $w$ prezentacji $i$ promocji świadczonych ustug. Badania przeprowadzono $w$ trzech płaszczyznach: responsywności przekazu, projektowej oraz ekonomicznej. Badaniom responsywności poddano 287 witryn internetowych gospodarstw agroturystycznych. W trakcie testów projektowych utworzono aplikacje mobilne dla modelowego gospodarstwa agroturystycznego. Ekonomiczne uwarunkowania utworzenia aplikacji mobilnych zbadano rozsylajac zapytanie ofertowe.

$W$ zbiorze badanych witryn nie odnotowano ani jednej witryny mobilnej. Żadne $z$ gospodarstw nie udostępniało też aplikacji mobilnej. Gospodarstwa agroturystyczne z badanego zbioru postugiwaty się przeważnie witrynami responsywnymi. Pracownicy ankietowanych podmiotów unikali $w$ swoich odpowiedziach tematu kosztów wykonania aplikacji mobilnej. Większość z nich zasugerowata, że z uwagi na kwestie praktyczne (efektywność) $i$ ekonomiczne, korzystniej jest promować gospodarstwo przy pomocy witryny internetowej dostosowanej do urzq̨dzeń przenośnych. W konkluzji wykazano, że powszechność wykorzystania aplikacji mobilnych $w$ promocji gospodarstw agroturystycznych jest ograniczana barierami: przydatności, kosztów, a także wiedzy i umiejętności.

Słowa kluczowe: promocja agroturystyki, technologie mobilne, witryny mobilne, responsywność przekazu, urządzenia mobilne

\section{Wstęp}

Urządzenia przenośne, na przestrzeni ostatnich kilkunastu lat, przeszły drogę od narzędzi umożliwiających komunikację głosową do mobilnych systemów informacyjnych wykorzystujących technologie wirtualnej rzeczywistości ${ }^{1}$. Rewolucja informacyjna doprowadziła do powstania społeczeństwa informacyjnego oraz gospodarki informacyjnej. Postęp technologiczny stał się katalizatorem rozwoju technologii mobilnych $^{2}$, które zapoczątkowały erę komunikacji mobilnej, „konwergujacej dotychczasowe paradygmaty komunikacji i opartej na skonwertowanych urzadzeniach, infrastrukturach i zawartości" ’3.

\footnotetext{
${ }^{1}$ J. Brzostek-Pawłowska: Między Web 2.0 i 3.0: Mobilne systemy informacyjne z rozszerzona rzeczywistościa, „Elektronika: konstrukcje, technologie, zastosowania”, 2010, nr 51(11), s. 79-88.

${ }_{2}^{2}$ Ł. Lysik, P. Machura: Rola $i$ znaczenie technologii mobilnych $w$ codziennym życiu człowieka XXI wieku, „Media i Społeczeństwo”, 2014, nr 4, s. 15-26.

${ }^{3}$ K. Kopecka-Piech: Mobilne media miejskie, ,Studia Medioznawcze”, 2012, nr 3 (50), s. 111.
} 
Mobilność współczesnego społeczeństwa stała się przejawem nowoczesności ${ }^{4}$. Dynamicznie rośnie liczba urządzeń przenośnych, dla których zasadniczym oprogramowaniem są dedykowane aplikacje ${ }^{5}$. Znajdują one coraz to nowe zastosowania, dostarczając zarówno użytkowych, jak i czysto ludycznych narzędzi budowania relacji z innymi użytkownikami ${ }^{6}$.

Technologie informacyjno-komunikacyjne (ICT) determinują sposób, w jaki konsumenci zdobywają wiedzę, zawierają transakcje handlowe i kształtują nowe zachowania nabywcze ${ }^{7}$. Do zasadniczych cech komunikacji za pośrednictwem aplikacji mobilnych należą: sytuacyjność, personalizacja i innowacyjność, a o jej wyjątkowości decydują przede wszystkim: kontekstowość (sytuacyjność), rozumiana jako docieranie do odbiorcy $\mathrm{w}$ „momentach podatności na komunikację” (moments of receptivity), osobista i emocjonalna relacja użytkowników z urządzeniem przenośnym, relatywnie niewielkie rozmiary samych urządzeń, prostota ich obsługi, przydatność oraz skuteczność i efektywność komunikacji za ich pośrednictwem ${ }^{8}$, . Wydaje się zatem zasadne, aby w obliczu złożoności zjawiska komunikowania mobilnego podejmować badania interdyscyplinarne, które ukażą jego społeczno-kulturowy, medialny, ekonomiczny i technologiczny wymiar ${ }^{10}$.

Celem pracy była ocena możliwości oraz stopnia wykorzystania przez gospodarstwa agroturystyczne witryn i aplikacji mobilnych $\mathrm{w}$ prezentacji i promocji świadczonych usług. W pracy postawiono pytanie badawcze: czy właściciele gospodarstw agroturystycznych posiadają witryny internetowe dostosowane do urządzeń mobilnych i czy wykorzystują aplikacje mobilne do promocji świadczonych usług?

\section{Aplikacje mobilne i marketing mobilny}

Zasadniczo istnieją trzy typy aplikacji tworzonych z myślą o urządzeniach mobilnych: witryny responsywne (RWD, AWD) lub mobilne (mobile web), aplikacje hybrydowe oraz aplikacje natywne (native apps). RWD (Responsive Web Design) to nowatorskie podejście do projektowania, które stawia na pierwszym miejscu potrzeby użytkownika oraz komfort przeglądania witryny (user centred design). Technologia RWD zakłada płynne skalowanie witryny z zachowaniem jakości obrazu oraz prostoty nawigacji ${ }^{11},{ }^{12}$.

\footnotetext{
4 J.B. Papińska-Kacperek: Miejskie aplikacje mobilne w turystyce kulturowej w Polsce, „Turystyka Kulturowa”, 2016, nr 2, s. 67.

5 A. Sznajder: Wpływ mobilnej technologii informacyjnej na dziatalność marketingowa przedsiębiorstw, "Gospodarka Narodowa”, 2013, nr 7, s. 37-61.

${ }^{6}$ K. Kopecka-Piech: Mobilne media miejskie..., op. cit., s. 111-126.

${ }^{7}$ E. Badzińska: Mobilność, interaktywność i zaangażowanie użytkowników jako wyzwania wspótczesnej komunikacji w biznesie, „Zeszyty Naukowe Uniwersytetu Szczecińskiego”, 2015, nr 41(1), s. 25.

8 J. Kall: Branding na smartfonie. Komunikacja mobilna marki, Oficyna a Wolters Kluwer Business, Warszawa 2015.

9 J. Kall: Planowanie komunikacji mobilnej marki, „Nierówności Społeczne a Wzrost Gospodarczy”, 2016, nr 45, s. $274-281$

${ }^{10}$ K. Kopecka-Piech: Aplikacje mobilne: innowacyjność, sytuacyjność i personalizacja komunikacji marketingowej i wizerunkowej, „Nowe Media. Studia i Rozprawy”, 2013, nr 4, s. 11-30.

${ }^{11}$ K. Król, D. Bedla: Ocena wykorzystania technologii responsywności w projektach witryn internetowych gospodarstw agroturystycznych, „Problemy Drobnych Gospodarstw Rolnych - Problems of Small Agricultural Holdings", 2015, nr 3, s. 53-65.
} 
Witryny adaptywne (Adaptive Web Design, AWD) również dostosowują się do urządzeń mobilnych, jednak odbywa się to w momencie, gdy przekroczony zostanie tzw. punkt adaptacyjny. W praktyce oznacza to, że wyświetlany jest projekt witryny zgodny $\mathrm{z}$ rozdzielczością wyświetlacza. $\mathrm{Z}$ kolei mobilne strony internetowe są tworzone wyłącznie dla urządzeń przenośnych. W tym miejscu warto wspomnieć, że rozwijana jest, wspierana przez Google, technologia przyspieszonych witryn mobilnych (Accelerated Mobile Pages, AMP), inicjatywa mająca na celu zwiększenie ich wydajności. Aplikacje natywne umożliwiają wykorzystanie technicznych komponentów urządzeń mobilnych np. geolokalizacji lub aparatu fotograficznego.

Aplikacje mobilne (mobile software, mobile application) to oprogramowanie obsługiwane przy pomocy odpowiednio zaprojektowanego interfejsu ${ }^{13}$, zwiększające funkcjonalność urządzeń mobilnych i wykorzystujące ich potencjał techniczny ${ }^{14}$. Tworzone są na konkretne platformy (systemy operacyjne), przy czym w Polsce najpopularniejsze są urządzenia z systemami Google Android, Apple iOS oraz Microsoft Windows Phone ${ }^{15}$. Można je podzielić na: osobiste (personal), informacyjne (perishable), transakcyjne (transaction oriented), lokalizacyjne (location specific), biznesowe (corporate) i rozrywkowe (entertainment) ${ }^{16}$, a także na: samodzielne, które działają bez dostępu do internetu, klienckie - dedykowane, tworzone na zamówienie, internetowe oraz gry mobilne ${ }^{17}$. Wyróżnić można też aplikacje preinstalowane na urządzeniach przenośnych oraz te, które są pobierane przez samych użytkowników ${ }^{18}$.

Aplikacje mobilne zmieniają współczesną konsumpcję, rewolucjonizują tworzenie i prezentację internetowej zawartości, stwarzają szansę unikalnej interakcji z klientem ${ }^{19}{ }^{20},{ }^{21}$. Podnoszą prestiż firmy i zmieniają jej postrzeganie ${ }^{22}$. Popularność

\footnotetext{
${ }^{12}$ K. Król, J. Halva: Measuring efficiency of websites of agrotouristic farms from Poland and Slovakia/Pomiar efektywności witryn internetowych gospodarstw agroturystycznych z Polski $i$ Stowacji, „Economic and Regional Studies", 2017, nr 10(2), s. 50-59.

${ }_{13}$ M. Borys, M. Plechawska-Wójcik: Badanie użyteczności oraz dostęności interfejsu w aplikacjach mobilnych, ,Nierówności Społeczne a Wzrost Gospodarczy”, 2013, nr 35, s. 63-78.

${ }_{14}^{14}$ J. Kall: Witryny i aplikacje mobilne w komunikacji marek odzieżowych, „Handel Wewnętrzny”, 2017, nr 2(367), s. $145-155$

${ }^{15}$ Udział w światowym rynku mobile należy obecnie do systemów operacyjnych: Google Android, który posiada $81.7 \%$ rynku oraz Apple iOS (17,9\% rynku). Liczba użytkowników posługujących się urządzeniami z systemem Windows Mobile spada. Urządzenia te stanowią obecnie 0,3\% rynku (Gartner: Market Share: Final PCs, Ultramobiles and Mobile Phones, All Countries, 4Q16, za: https://goo.gl/19sJ8c, data dostępu: 24.09.2017.

${ }^{16}$ A.K. Talukder, R.R. Yavagal: Mobile Computing: Technology Applications and Service Creation, McGrawHill Companies, New York 2007.

${ }^{17}$ R. Rasińska, W. Siwiński: Aplikacje mobilne jako innowacyjne źródła informacji turystycznej dla studentów, „Rozprawy Naukowe Akademii Wychowania Fizycznego we Wrocławiu”, 2015, nr 50, s. 74-80.

${ }_{18}$ A. Jasiulewicz: Aplikacje mobilne jako innowacyjne narzędzie marketingu mobilnego na rynku żywności, „Zeszyty Naukowe Uniwersytetu Szczecińskiego. Problemy Zarządzania, Finansów i Marketingu”, 2015, nr 41, T. 1, s. 315-326.

${ }^{19}$ E. Sadowska: Marketing mobilny a komunikacja marketingowa, „Studia Ekonomiczne”, 2013, nr 140, s. $122-132$.

${ }^{20} \mathrm{C}$. Watson, J. McCarthy, J. Rowley: Consumer attitudes towards mobile marketing in the smart phone era, „International Journal of Information Management”, 2013, nr 33(5), s. 840-849.

${ }^{21}$ V. Shankar, M. Kleijnen, S. Ramanathan, R. Rizley, S. Holland, S. Morrissey: Mobile Shopper Marketing: Key Issues, Current Insights, and Future Research Avenues, „Journal of Interactive Marketing”, 2016, nr 34, s. $37-48$.
} 
aplikacji mobilnych oraz innych usług dostępnych za pośrednictwem urządzeń przenośnych wywołała rozwój nowych form marketingu, w tym marketingu mobilnego ${ }^{23}$. Własne aplikacje sprzedażowe marek to innowacja $\mathrm{w}$ marketingu wielokanałowym, która spełnia funkcję sprzedażową i informacyjną ${ }^{24},{ }^{25}$. Pomimo rosnącej liczby aplikacji mobilnych, dynamika rozwoju ich rynku ograniczana jest przez relatywnie niski poziom wiedzy użytkowników na temat posiadanych urządzeń i ich możliwości ${ }^{26}$.

Rola gospodarcza technologii mobilnych rośnie równie szybko jak ich znaczenie społeczne ${ }^{27}$. W 2015 roku za pośrednictwem kanałów mobilnych Polacy dokonali zakupów za kwotę 2,5 miliarda złotych i przesłali 559 milionów gigabajtów danych, o $114 \%$ więcej niż rok wcześniej ${ }^{28}$. Z kolei rok 2016 przeszedł do historii jako ten, w którym po raz pierwszy liczba odsłon witryn internetowych dokonana z urządzeń mobilnych przewyższyła te dokonane przy pomocy komputerów ${ }^{29}$. Mobilnymi „konsumentami jutra” są przede wszystkim młodzi ludzie, pomiędzy 18 a 24 rokiem życia, z tzw. Generacji M, reprezentujący ,pokolenie mobilne”, którzy dorastali lub dorastaja $w$ czasach internetu ${ }^{30}$. Aż $80 \% \mathrm{z}$ nich korzysta $\mathrm{z}$ urządzeń przenośnych bez przerwy ${ }^{31}$. Kluczowy wpływ na wzrost „rynku mobilnego” ma przydatność urządzeń przenośnych, które znajdują coraz to nowe zastosowania ${ }^{32}$.

\section{Aplikacje mobilne w turystyce}

Powszechność internetu oraz popularność i dostępność technologii mobilnych wpływa na wiele dziedzin życia, w tym także na sposób uprawiania turystyki ${ }^{33}$. Współczesny turysta istotną czesść swoich potrzeb, zwłaszcza tych skierowanych na transfer i przetwarzanie informacji, zaspokaja $\mathrm{W}$ przestrzeni stworzonej przez systemy

\footnotetext{
22 A. Jasiulewicz, M. Wiaderny: Aplikacje mobilne jako innowacyjne narzędzia promocji marki w opinii konsumentów, „Logistyka”, 2015, nr 2, s. 1229-1236.

${ }^{23}$ V. Shankar, S. Balasubramanian: Mobile marketing: A synthesis and prognosis, „Journal of Interactive Marketing", 2009, nr 23 (2), s. 118-129.

${ }^{24}$ A. Jasiulewicz: Aplikacje mobilne jako innowacja marketingowa, „Marketing i Rynek”, 2015, nr 8, s. 224232

${ }^{25}$ A. Jasiulewicz: Aplikacje mobilne jako innowacyjne narzędzie... op. cit., s. 315-326.

${ }^{26}$ K. Piekarz: Trendy rozwojowe - potencjat $i$ bariery, w: „Raport IAB Polska: Perspektywy rozwojowe mobile online w Polsce 2015”, 2015, s. 14-16, za: https://goo.gl/NmSwsq, data dostępu: 10.09.2017.

${ }^{27}$ Ł. Lysik, P. Machura: op. cit., s. 15-26.

${ }^{28}$ PwC: Technologie mobilne $w$ nowoczesnej Polsce - odpowiedzialny rozwój $i$ równe szanse, Polska Izba Informatyki i Telekomunikacji, 2016, za: https://goo.gl/QRHfSd, data dostępu: 10.09.2017.

${ }^{29}$ B. Chabior: Rynek marketingu mobilnego, „Raport Interaktywnie.com: Marketing Mobilny”, 2016, 6-13, za: https://goo.gl/s1ouo7, data dostępu: 05.09.2017.

30 A.J. Rohm A.J., T. Gao, F. Sultan, M. Pagani: Brand in hand: a cross-market investigation of consumer acceptance of mobile marketing, „Business Horizons”, 2012, nr 55 (5), s. 485-493.

${ }^{31}$ B. Chochołowski: Za każda wersja systemu stoja potencjalni klienci. Bliska śmierć Windows Phone'a nie uprości rynku, ,Raport Interaktywnie.com: Marketing Mobilny”, 2016, s. 21-28, za: https://goo.gl/s1ouo7, data dostępu: 05.09.2017.

${ }^{32}$ H. Kennedy-Eden, U. Gretzel: A taxonomy of mobile applications in tourism, ,e-Review of Tourism Research", 2012, nr 10 (2), s. 47-50.

${ }^{33}$ U. Kęprowska: Zastosowanie marketingu mobilnego $w$ branży turystycznej, „Handel Wewnętrzny”, 2014, $\mathrm{nr}$ 6 (353), s. 207-220.
} 
teleinformatyczne, portale, aplikacje i procesy internetowe ${ }^{34}$. Wykorzystanie technologii telekomunikacyjnych, w szczególności mobilnych, stworzyło bowiem nowe możliwości w zakresie komunikacji marketingowej ${ }^{35},{ }^{36}$. Analitycy prognozują, że aplikacje mobilne mogą być jednym z głównych czynników rozwoju branży turystycznej ${ }^{37}$. Wykorzystanie aplikacji mobilnych może spowodować wzrost popytu turystycznego, rozwoju regionalnego, a także bezpieczeństwa i komfortu wypoczynku ${ }^{38}$.

Do głównych form mobilnej komunikacji marketingowej stosowanych przez podmioty świadczące usługi turystyczne zaliczyć można: infolinie, SMS i MMS, serwisy internetowe $\mathrm{i}$ aplikacje mobilne ${ }^{39}$. Aplikacje mobilne $\mathrm{w}$ turystyce to przejaw zastosowania $\mathrm{w}$ tej dziedzinie technik informacyjnych i komunikacyjnych, czyli domena e-turystyki ${ }^{40}$. E-turystyka jest postrzegana przede wszystkim przez pryzmat programów, aplikacji i urządzeń, które w sposób znaczący ułatwiają uprawianie turystyki ${ }^{41}$.

Dynamicznie rozwijający się rynek urządzeń mobilnych stworzył techniczną możliwość przygotowania mobilnych, multimedialnych katalogów i przewodników ${ }^{42}$. Aplikacje mobilne biur podróży stają się coraz bardziej popularne. Umożliwiają one przeglądanie ofert i usprawniają rezerwację usług ${ }^{43}$. Jedne $z$ pierwszych na polskim rynku turystycznym aplikacji mobilnych, które nadały nowy wymiar prezentacji oferty turystycznej, udostępniły największe na rynku biura podróży. Aplikacje te swą atrakcyjność oparły na przydatności (funkcjonalności) i użyteczności, a także walorach wirtualnej, rozszerzonej rzeczywistości (Augmented Reality, AR) ${ }^{44}$. Technologię tą wykorzystano także w aplikacji „Google Goggles”, która dostarcza informacji między innymi o danym miejscu lub obiekcie w oparciu o fotografie wykonane w czasie rzeczywistym ${ }^{45}$. Multimedialne i interaktywne panoramy sferyczne stanowią komponent wielu witryn internetowych i aplikacji mobilnych. Przykładem może być aplikacja udostępniana przez Kopalnię Soli Wieliczka ${ }^{46},{ }^{47}$. Z myślą o urządzeniach mobilnych

${ }^{34}$ D.E. Jaremen, I. Michalska-Dudek, A. Rapacz: Wirtualizacja zachowań konsumentów na rynku turystycznym jako źródło wiedzy w podejmowaniu decyzji marketingowych, „Studia i Prace WNEiZ US”, 2016, nr 43(2), s. 87.

${ }^{35}$ N. Piechota: Lokalizacyjna aplikacja mobilna jako narzędzie badań ruchu turystycznego w miastach, „Studia Oeconomica Posnaniensia", 2014, nr 2(1), s. 115-133.

${ }^{36}$ J.J. Hew, V.H. Lee, L.Y. Leong, T.S. Hew, K.B. Ooi: The dawning of mobile tourism: what contributes to its system success? „International Journal of Mobile Communications”, 2016, nr 14(2), s. 170-201.

${ }^{37}$ M. Rudnicki: Wykorzystanie aplikacji mobilnej jako innowacyjnego kanału komunikacji przedsiębiorstw rynku turystycznego z konsumentami na przykładzie Kopalni Soli Wieliczka, „Prace Naukowe Uniwersytetu Ekonomicznego we Wrocławiu. Gospodarka turystyczna w regionie: wybrane problemy funkcjonowania regionów, gmin i przedsiębiorstw turystycznych", 2013, nr 303, s. 235-246.

${ }^{38}$ R. Rasińska, W. Siwiński: op. cit., s. 74-80.

39 M. Kieżel, J. Wiechoczek: Kierunki rozwoju mobilnej komunikacji marketingowej $w$ ustugach na przykładach uslug bankowych i turystycznych, „Zeszyty Naukowe Uniwersytetu Szczecińskiego. Problemy Zarządzania, Finansów i Marketingu", 2013, nr 32, s. 339-355.

${ }^{40}$ A. Pawlicz: E-turystyka, Wydawnictwo Naukowe PWN, Warszawa 2012, s. 18.

${ }^{41}$ J. Kalecińska: Nowe technologie w branży turystycznej, AWF, Warszawa 2013, za: https://goo.gl/9f2URF, data dostępu: 14.05.2017.

${ }^{42}$ R. Pelc-Mieczkowska: Koncepcja pozyskania danych na potrzeby multimedialnego przewodnika mobilnego po szlakach turystycznych, ,Roczniki Geomatyki - Annals of Geomatics”, 2015, nr 13(1 (67)), s. 47-56.

43 J. Olearnik, K. Pasek: Innowacyjność $w$ turystyce $i$ jej oddzialywanie promocyjne, „Rozprawy Naukowe Akademii Wychowania Fizycznego we Wrocławiu", 2014, nr 46, s. 91-102.

${ }^{44}$ E. Badzińska: op. cit., s. 25-37.

${ }^{45}$ J. Kalecińska: op. cit.

${ }^{46}$ M. Rudnicki: op. cit., s. 235-246. 
przygotowano także aplikację „Agroturystyka. Wieś polska zaprasza”, która udostępnia bazę ponad tysiąca obiektów agroturystycznych rekomendowanych przez Polską Federację Turystyki Wiejskiej „Gospodarstwa Gościnne”. Aplikacja pełni też rolę multimedialnego przewodnika. Dostępne są również aplikacje: „Małopolska Wieś dla Dzieci”, a także „Małopolska Wieś w Siodle” oraz „Małopolska Wieś dla Seniorów”. Projekty te zrealizowano przy wsparciu finansowym Województwa Małopolskiego w ramach konkursu ofert z turystyki pn. „Małopolska Gościnna”. W sklepie Google Play można ponadto pobrać aplikacje „Agriturismo On Line” lub „Italia - Agriturismo”, które mogą okazać się pomocne dla urlopowiczów zainteresowanych agroturystyką we Włoszech, aplikację „Falusi turizmus szálláskereső” dla turystów zainteresowanych turystyką wiejską na Węgrzech lub aplikacje „Turismo Rural Murcia” promującą turystyką na obszarach wiejskich Hiszpanii.

\section{Materiały i metody}

Badania przeprowadzono w trzech płaszczyznach: „responsywności przekazu”, projektowej (inżynierskiej) oraz ekonomicznej. Badania responsywności przekazu oparto o analizę stopnia dostosowania witryn internetowych gospodarstw agroturystycznych do urządzeń mobilnych. Witryny przeglądano metodą inspekcyjną (manualnie), co pozwoliło zidentyfikować rozwiązania odpowiadające za ich responsywność (założenia i techniki projektowe: RWD, AWD, mobile web) oraz narzędzia zastosowane do osiagnięcia efektu responsywności. Tak pozyskane wyniki weryfikowano na dwa sposoby (walidacja krzyżowa): przy pomocy aplikacji internetowej Complex SEO Audit, która wspomogła identyfikację systemu zarządzania treścią CMS (Content Management System), a także komponentów rozszerzających funkcjonalność i interaktywność witryny, oraz przy pomocy emulatora urządzeń mobilnych na komputerach stacjonarnych ${ }^{48}$ - aplikacji Opera Mobile Classic Emulator, która umożliwia przeglądanie witryn internetowych w oknie wybranego urządzenia mobilnego w przeglądarce Opera Mini ${ }^{49}$.

Badaniom responsywności poddano 287 witryn internetowych gospodarstw agroturystycznych, których adresy pozyskano z jednego z ogólnopolskich katalogów witryn. Do badań zakwalifikowano tylko takie witryny, które zostały opublikowane w domenie krajowej najwyższego poziomu (domena '.pl', ccTLD country code top-level domain). Przyjęto bowiem założenie, że właściciele domen abonamentowych przykładają większą wagę do techniki wykonania witryn i jakości publikowanych treści. Ponadto do badań zakwalifikowano witryny obiektów, które zadeklarowały działalność agroturystyczną ( $\mathrm{w}$ nagłówku witryny lub w opublikowanych treściach). Witryny internetowe innych podmiotów z rynku turystycznego, choć umieszczone w katalogu w kategorii ,agroturystyka”, nie zostały wzięte pod uwagę.

\footnotetext{
${ }^{47}$ M. Kieżel, J. Wiechoczek: op. cit., s. 339-355.

${ }^{48} \mathrm{Na}$ rynku dostępnych jest wiele typów i modeli urządzeń przenośnych o różnej konfiguracji sprzętowej oraz oprogramowaniu. W praktyce możliwe jest przetestowanie użyteczności witryn $\mathrm{i}$ aplikacji jedynie na wybranych, będących w posiadaniu programisty. W takich przypadkach pomocne bywają programy emulujące działanie określonej gamy urządzeń. Emulacja to symulowanie działania określonego programu lub platformy sprzętowej przez inny system lub na sprzęcie innego typu.

${ }^{49}$ Opera Mini jest jedną z najpopularniejszych w świecie przeglądarek mobilnych.
} 
W drugiej płaszczyźnie ujęto kwestie utworzenia i wykorzystania aplikacji mobilnej $\mathrm{w}$ promocji indywidualnego gospodarstwa agroturystycznego. Testom funkcjonalności poddano trzy popularne serwisy internetowe: Mobincube, Marvel i Proto, umożliwiające samodzielne zaprojektowanie aplikacji mobilnej. Aplikację wykonano dla modelowego gospodarstwa agroturystycznego „Ostoja”.

Ekonomiczne uwarunkowania utworzenia aplikacji mobilnych zbadano przy pomocy metody z rodzaju „tajemniczy klient” (mystery shopper). Metoda ta jest często stosowana w badaniach marketingowych, w szczególności w handlu i usługach. Pozwala ocenić zaangażowanie pracowników w kontakt $\mathrm{z}$ klientem oraz pozyskać informacje o charakterze świadczonej usługi ${ }^{50}$. W metodzie tej stosuje się obserwację, która jest: niejawna (ukryta) - podmiot nie jest informowany, że bierze udział w badaniu, a także kontrolowana i standaryzowana - audytor postępuje według ustalonego wcześniej scenariusza, a wyniki obserwacji ujmuje $\mathrm{w}$ raporcie końcowym ${ }^{51}$.

Do pozyskania informacji wykorzystano zapytanie ofertowe zredagowane $\mathrm{w}$ imieniu właściciela gospodarstwa agroturystycznego „Ostoja”. Zawarto w nim pytania o możliwość zastosowania aplikacji mobilnej w promowaniu gospodarstwa i kosztach związanych $\mathrm{z}$ jej wykonaniem. Zapytanie wysłano e-mailem do 15 firm wyspecjalizowanych $\mathrm{w}$ tworzeniu aplikacji mobilnych. Adresy firm pozyskano $\mathrm{z}$ wyników organicznych wyszukiwarki Google, uzyskanych po wpisaniu frazy „wykonujemy aplikacje mobilne”.

\section{Wyniki i wnioski}

$\mathrm{W}$ zbiorze badanych witryn nie odnotowano ani jednej witryny mobilnej. Żadne z gospodarstw nie udostępniało też aplikacji mobilnej. Gospodarstwa agroturystyczne z badanego zbioru posługiwały się przeważnie witrynami responsywnymi. Odnotowano 130 takich witryn (45\%). Emulacja prezentacji witryn (ryc. 1) wykonana przy pomocy aplikacji Opera Mobile Classic Emulator na telefonie Samsung Galaxy SIII pokazała, że $126(97 \%)$ spośród nich charakteryzuje użyteczność na platformie Android w rozdzielczości ekranu HD Portrait $720 x 1280 \mathrm{px}$. W pozostałych przypadkach przeglądanie witryn utrudniały zbyt małe elementy nawigacji oraz niewielkich rozmiarów tekst. Potwierdza to zasadność testów krzyżowych, tj. wykonywanych różnymi technikami, przy użyciu co najmniej dwóch narzędzi testujących.

W 18 przypadkach responsywność witryny realizowana była za pośrednictwem narzędzia Bootstrap ${ }^{52}$. W 111 przypadkach responsywność wynikała z zastosowania systemu CMS dostosowanego do urządzeń przenośnych. W zbiorze badanych witryn najpopularniejsze były: WordPress (74 witryny) oraz Joomla! (22 witryny).

\footnotetext{
${ }^{50} \mathrm{~K}$. Król: Kalkulacja kosztów wykonania oraz promocji strony internetowej gospodarstwa agroturystycznego, „Acta Sci. Pol. Formatio Circumiectus”, 2015, nr 14(4), s. 41-48.

${ }_{51}$ M. Mękarski: Mystery shopping oraz shadowing jako metody badania kultury, „Roczniki Kulturoznawcze”, 2017, nr 5(1), s. 53-71.

52 Framework, zestaw narzędzi ułatwiających tworzenie interfejsu graficznego stron oraz aplikacji internetowych.
} 


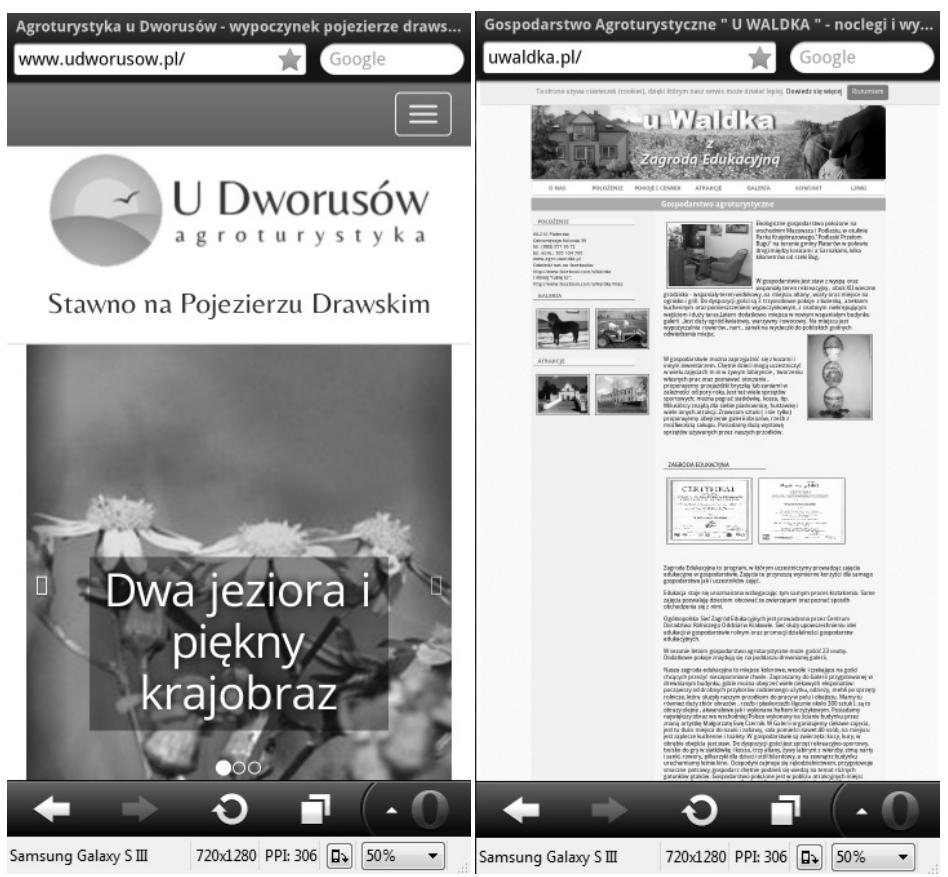

Rycina 1. Witryna internetowa responsywna (udworusuw.pl) oraz witryna „klasyczna” (Waldka.pl) Źródło: opracowanie własne przy pomocy Opera Mobile Classic Emulator

\section{Wyniki testów projektowych}

W trakcie testów projektowych utworzono aplikacje mobilne o podstawowych funkcjonalnościach, adekwatnych do tych udostępnianych na stronie internetowej responsywnej lub mobilnej. Aplikacja mobilna, która udostępnia funkcjonalności oraz treści zbliżone lub identyczne do swojego internetowego odpowiednika (witryny responsywnej lub mobilnej) może rozczarować użytkownika. Jej instalacja wymaga dodatkowych czynności, podczas gdy witryna dostępna jest bezpośrednio w oknie przeglądarki. Inwestycja w aplikacje mobilną jest więc zasadna, gdy przynosi realne korzyści, umożliwia lub ułatwia czynności sprzedażowe.

Samodzielne utworzenie, opublikowanie i uruchomienie aplikacji mobilnej pozwala lepiej zrozumieć tę formę komunikacji marketingowej. Testowane serwisy różnią się oprawą graficzną interfejsu, jednak zasada ich działania jest w każdym z przypadków oparta o założenia WYSIWYG (ang. What You See is What You Get, produkt końcowy jest identyczny lub zbliżony do efektów uzyskanych w kreatorze). Proces kreacji odbywa się w oknie przeglądarki internetowej przy pomocy graficznego interfejsu (ang. graphical user interface, GUI). Efekty pracy można przeglądać w symulowanym oknie urządzenia przenośnego (ryc. 2). Jest kwestią względną (subiektywną), które $\mathrm{z}$ narzędzi jest bardziej funkcjonalne i użyteczne, choć mają one wspólne cechy. W przypadku aplikacji 'Mobincube' możliwe jest skorzystanie z bezpłatnych funkcjonalności pakietu startowego, co jest jednak związane $\mathrm{z}$ 
„wbudowaniem” w aplikację treści reklamowych narzucanych przez usługodawcę. Bezpłatny pakiet startowy (o limitowanych parametrach) dostępny jest także w ramach serwisu 'Marvel'. Z funkcjonalności serwisu 'Proto' korzystać można podczas okresu próbnego (licencja trial).
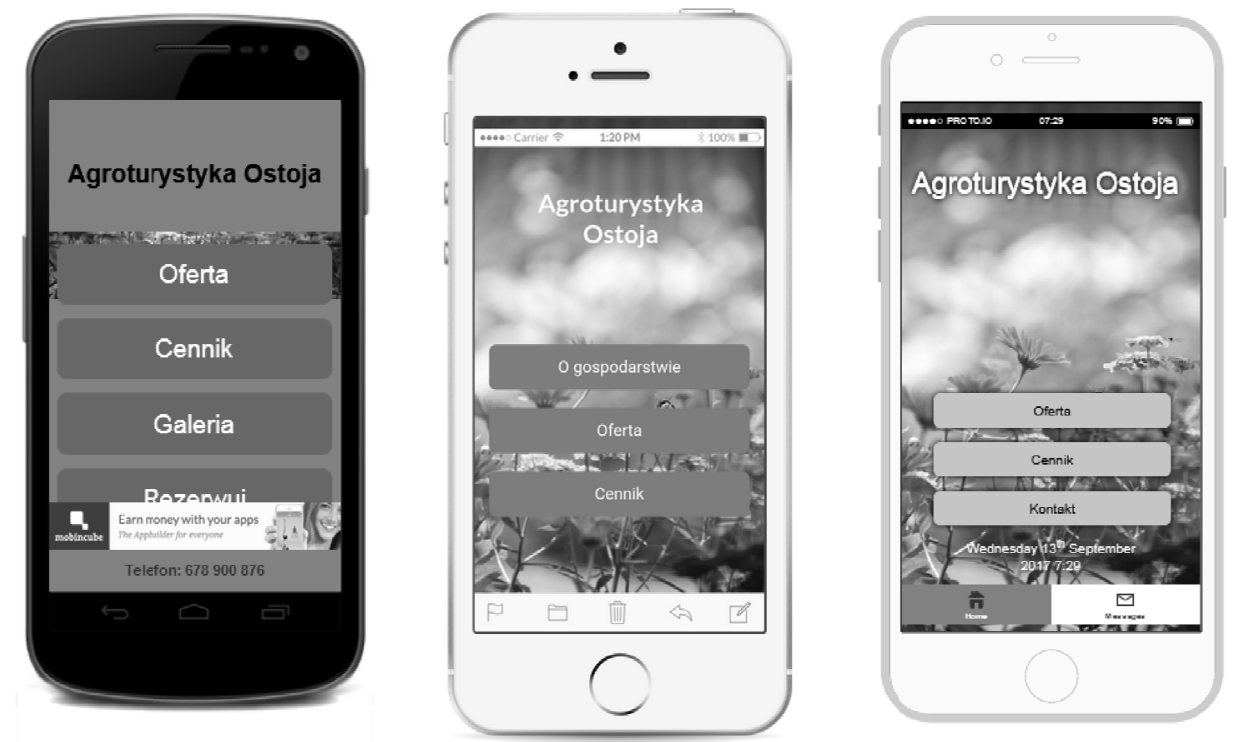

Rycina 2. Prezentacja aplikacji mobilnej „Agroturystyka Ostoja”, na wyświetlaczu urządzenia mobilnego, utworzonej przy pomocy (od lewej): Mobincube, Marvel i Proto

Źródło: opracowanie własne przy pomocy Mobincube, Marvel i Proto

\section{Wyniki badań ankietowych}

$\mathrm{Na}$ zapytanie ofertowe odpowiedziało osiem podmiotów. Analizując formę i styl pozyskanych wypowiedzi zwrócono uwagę, że większość z nich sprawiało wrażenie redagowanych $\mathrm{w}$ pośpiechu, bez specjalnego zaangażowania, choć zawierały one kurtuazyjne zwroty, takie jak podziękowanie za zainteresowanie ofertą (pięć przypadków). Ponadto odpowiedzi, choć zasadniczo poprawne, były krótkie (często zdawkowe) i niedopracowane $\mathrm{w}$ detalach (np. literówki, skróty, kolokwializmy). W jednym przypadku firma zredagowała odpowiedź do kobiety, podczas gdy zapytanie podpisane było przez mężczyznę. W pięciu przypadkach odpowiedź przyjęła krótką formę zaproszenia do współpracy i kontaktu telefonicznego.

Ankietowane podmioty niechętnie dzieliły się informacjami o kosztach wykonania przedmiotowej aplikacji. Jedynie dwa z nich oszacowały koszty jej utworzenia. Informacja ta może być niechętnie udzielana z uwagi na jej „strategiczną wartość" (w kontekście konkurencyjności), a także z uwagi na trudności w oszacowaniu kosztów realizacji danego zlecenia bez ustalenia szczegółów (bez konkretnej specyfikacji projektowej). Wykonanie aplikacji mobilnej prezentującej ofertę, umożliwiającej złożenie rezerwacji i wykonanie płatności wyceniono, w jednym 
przypadku na 4700 zł netto, a w drugim na 3000 zł netto. Co ważne była to wycena wykonania aplikacji jedynie na jedną platformę.

Ankietowani $\mathrm{w}$ swoich odpowiedziach nie wdawali się $\mathrm{w}$ polemikę, czy utworzenie aplikacji mobilnej jest zasadne czy też nie, choć większość z nich sugerowała, że $\mathrm{z}$ uwagi na kwestie praktyczne (efektywność, przydatność) i ekonomiczne jest najkorzystniej utworzyć witrynę internetową dostosowaną do urządzeń przenośnych. Realia wykorzystania aplikacji mobilnych w promocji indywidualnego gospodarstwa agroturystycznego zdradzają fragmenty wypowiedzi udzielonych na zapytanie ofertowe:

„Aplikacje mobilne sq droższe $w$ wykonaniu $i$ utrzymaniu od responsywnej strony internetowej. Wynika to głównie z faktu, że w przypadku aplikacji mobilnej wykonuje się niejako do trzech odrębnych projektów tzn. na system iOS, Android $i$ Windows. Strona internetowa będzie jedna $i$ technologicznie prostsza do zaadaptowania" - JCommerce SA, outsourcingu usług IT, oprogramowanie dedykowane, Business Intelligence, aplikacje webowe, mobilne i desktopowe.

„Jeżeli chodzi o wybór między responsywna strona internetowa a aplikacja, to myśle że w tym przypadku ewidentnie bardziej praktycznym wydaje się wybór responsywnej strony, gdyż można używać jej także na zwyktych komputerach, a na telefonach jest praktycznie równie funkcjonalna co aplikacja" - ALLSET, witryny internetowe, pozycjonowanie, marketing internetowy, hosting.

"Strona responsywna będzie tańsza $i$ będzie tatwiej ja ,wypozycjonować” $w$ Google. Natomiast aplikacja daje całkiem inne możliwości dodatkowe w porównaniu ze stronq. Mimo wszystko dla tego typu działalności (agroturystycznej, red.) skłaniałbym się do stworzenia profesjonalnej strony z kalendarzem i platnościami online $w$ wersji $R W D$, czyli dostosowanej do urzqdzeń mobilnych" - Agencja Reklamowa Jarocin, kompleksowe usługi reklamowe.

„Dla Pana zastosowania (w promocji gospodarstwa agroturystycznego, red.) uważamy, że aplikacja nie będzie dobrym wyborem (aplikacja wymaga pobrania, a tutaj nie przynosi dla użytkownika potencjalnych korzyści, które uzasadnialyby instalacje czegoś na telefonie)" - GSWtech, dedykowane systemy informatyczne, serwisy internetowe, aplikacji mobilne.

Przeprowadzona analiza pozwala wnioskować, że witryny i aplikacje mobilne, z uwagi na swój charakter (tab. 1), to narzędzia, które mogą być i są obecnie częściej wykorzystywane przez organizacje, jednostki administracji i samorządu terytorialnego, a także duże podmioty prowadzące działalność skomercjalizowaną, czy wręcz korporacyjną. 
Tabela 1. Porównanie wybranych atrybutów witryn responsywnych, mobilnych stron internetowych i aplikacji mobilnych

\begin{tabular}{|l|l|l|l|}
\hline Atrybuty & $\begin{array}{l}\text { Witryna } \\
\text { mobilna }\end{array}$ & $\begin{array}{l}\text { Witryna } \\
\text { responsywna }\end{array}$ & $\begin{array}{l}\text { Aplikacja } \\
\text { mobilna }\end{array}$ \\
\hline $\begin{array}{l}\text { Nakłady pracy i kosztochłonność (utworzenie oraz } \\
\text { utrzymanie) }\end{array}$ & ++ & + & +++ \\
\hline Uniwersalność & ++ & +++ & + \\
\hline $\begin{array}{l}\text { Integracja z funkcjami mobilnego urządzenia i } \\
\text { systemu operacyjnego }\end{array}$ & $\begin{array}{l}\text { częściowa, } \\
\text { niedoskonała }\end{array}$ & $\begin{array}{l}\text { częściowa, } \\
\text { niedoskonała }\end{array}$ & pełna \\
\hline $\begin{array}{l}\text { Stopień wykorzystania narzędzi wbudowanych w } \\
\text { urządzenia mobilne }\end{array}$ & ++ & + & +++ \\
\hline Wymóg instalacji & - & - & + \\
\hline $\begin{array}{l}\text { Widoczność w wynikach wyszukiwania (Google } \\
\text { friendly) }\end{array}$ & + & + & - \\
\hline $\begin{array}{l}\text { Wrażliwość na aktualizacje systemu operacyjnego } \\
\text { (środowiska pracy, oprogramowania serwera) }\end{array}$ & ++ & + & +++ \\
\hline $\begin{array}{l}\text { Konieczność aktualizacji oprogramowania przez } \\
\text { użytkownika }\end{array}$ & - & - & + \\
\hline Rozbudowane funkcjonalności w trybie offilne & - & - & + \\
\hline Początkowy stopień trudności obsługi & + & + & +++ \\
\hline
\end{tabular}

Źródło: opracowanie własne

\section{Podsumowanie}

Aplikacje mobilne znajdują obecnie zastosowanie w promowaniu miast i regionów. Są często wykorzystywane przez touroperatorów, organizacje turystyczne i większe podmioty z sektora turystyki skomercjalizowanej, w tym z branży hotelarskiej.

Utworzone aplikacje pełnią przede wszystkim funkcję informacyjną i promocyjną (marketingową). Nie wnoszą żadnej wartości dodanej ponad funkcjonalności możliwe do zaprojektowania na stronie internetowej. Inwestycja w utworzenie i promocję aplikacji mobilnej o tak ograniczonych funkcjonalnościach jest obecnie nieuzasadniona ekonomicznie.

Badania pokazuja, że innowacyjne rozwiązania projektowe oraz marketingowe są przez gospodarstwa agroturystyczne zauważane i wykorzystywane $z$ pewnym opóźnieniem, zwłaszcza $\mathrm{W}$ stosunku do touroperatorów lub podmiotów $\mathrm{z}$ branży hotelarskiej ${ }^{53}$. Powodów tego zjawiska jest wiele. Nie bez znaczenia jest skala i charakter działalności agroturystycznej. W gospodarstwach agroturystycznych tzw. klasycznych, gospodarze nierzadko nie są zainteresowani maksymalizacją obłożenia kwater, pogonią za rentownością i zyskiem, a sama agroturystyka często stanowi dodatkowe źródło dochodów. Podobnie traktowana jest komunikacja marketingowa.

Zainteresowanie nowymi technologiami i marketingiem internetowym wśród podmiotów świadczących usługi agroturystyczne skomercjalizowane bywa nieco większe. Znajduje to potwierdzenie w jakości witryn internetowych, które posiadają. Niepublikowane wyniki badań przeprowadzonych przez autora pokazały, że gospodarstwa agroturystyczne znajdują się obecnie na etapie ,wymiany” dotychczas posiadanych witryn na wersje responsywne, przy czym proces ten został zapoczątkowany w 2012 roku i nabrał dynamiki w 2015 roku.

${ }^{53}$ K. Król: Globalne zmiany technologiczne $i$ ich wplyw na promocję agroturystyki $w$ internecie, ,Roczniki Naukowe Ekonomii Rolnictwa i Rozwoju Obszarów Wiejskich”, 2016, nr 103(3), s. 84-100. 
Aplikacje mobilne nie są obecnie wykorzystywane w promowaniu indywidualnych gospodarstw agroturystycznych przede wszystkim z uwagi na koszty ich utworzenia (zwykle dla dwóch lub trzech platform), utrzymania (aktualizacji), rozwijania i promocji. Ponadto osiagnięcie dynamicznego wzrostu pobrań aplikacji wymaga nie tylko dostępu do urządzeń przenośnych, usług (internetu mobilnego), ale także kompetencji w ich użytkowaniu. Branża mobile jest stosunkowo młoda, a wiedza użytkowników o możliwościach wykorzystania aplikacji mobilnych i korzyściach z tego płynących jest relatywnie niewielka. Jeszcze mniejsza jest świadomość zagrożeń jakie są związane $i$ ich użytkowaniem. Do pokonania pozostaje więc bariera wiedzy i umiejętności, bowiem aplikacje mobilne wciąż są produktem dla określonej grupy (zaawansowanych) użytkowników. Należy poruszyć także kwestie realnej przydatności aplikacji mobilnych w promocji indywidualnych gospodarstw agroturystycznych. O ile w przypadku portali ogólnopolskich, tworzonych przez różnorakie podmioty związane z agroturystyką i serwisów branżowych, grupujących oferty noclegów, wykorzystanie aplikacji mobilnych może być uzasadnione ekonomicznie, o tyle w przypadku gospodarstw agroturystycznych już nieco mniej, lub wręcz w ogóle. Pojawia się bowiem pytanie jaką funkcjonalność będzie miała aplikacja, której nie mogłaby mieć witryna responsywna lub mobilna? Co zachęciłoby użytkownika do jej pobrania? Wreszcie, czy nakłady poniesione na jej utworzenie mają szansę się zwrócić? Wszystko to skłania do wniosku, że aplikacje mobilne mogą obecnie znaleźć zastosowanie w promocji obiektów, które świadczą usługi agroturystyki skomercjalizowanej. Warunkiem jest duża skala działalności i specjalizacja. Obiekty te mogą dysponować środkami na inwestycję w aplikacje mobilne, których główną funkcjonalnością powinna być możliwość rezerwacji i płatności za usługę w czasie rzeczywistym.

Kluczem do powodzenia aplikacji jest jej przydatność. Rynek usług agroturystycznych stanowi więc wyzwanie dla twórców aplikacji mobilnych, zwłaszcza $\mathrm{w}$ kontekście wdrożenia ich $\mathrm{w}$ indywidualnych obiektach, a jednym $\mathrm{z}$ największych może być przekonanie użytkownika, że wykorzystanie aplikacji mobilnej przyniesie mu w tym konkretnym przypadku określone korzyści. Jest to swoista „bariera przydatności”, która jest ściśle związana z barierą „częstości użycia”. Brak faktycznej przydatności przełoży się bowiem na znikome zainteresowanie aplikacją. Istnieje jeszcze jedna bariera, zwykle pomijana, którą można określić „barierą zaangażowania”. Otóż aplikacja mobilna może odnieść sukces jedynie przy dużym zaangażowaniu $\mathrm{w}$ jej promocję. Jest to związane m.in. z działaniami z zakresu optymalizacji prezentacji (w tym opisu) aplikacji w sklepie z aplikacjami (app store optimization, ASO), wykorzystaniem innych kanałów promocji np. Google, YouTube lub mediów społecznościowych. Wymaga to czasu, pracy, cierpliwości, chęci, wiedzy i umiejętności. Wszystko to może zniechęcić właścicieli gospodarstw agroturystycznych do korzystania $\mathrm{z}$ tej formy promocji (prezentacji) świadczonych usług.

Aplikacje mobilne nie są obecnie w stanie wypracować dla indywidualnego gospodarstwa agroturystycznego wartości dodanej, która pokryłaby koszty związane z ich utworzeniem i utrzymaniem. Gospodarstwa agroturystyczne powinny więc zwrócić szczególną uwagę na technikę wykonania witryn, które posiadaja, aby umożliwiała ich komfortowe przeglądanie na urządzeniach mobilnych. Aplikacje mobilne będą wykorzystywane w promocji (rezerwacji, sprzedaży) gospodarstw agroturystycznych, gdy staną się tak powszechne jak witryny internetowe, co jeszcze w nie tak odległej 
przeszłości wydawało się skądinąd odległą perspektywą. W przyszłości zaś mogą być swoistym wyróżnikiem gospodarstwa, świadczącym o jego nowoczesności. Przydatność oraz spadek kosztów utworzenia i utrzymania aplikacji mobilnych będą warunkować dalszy wzrost ich powszechności. Pomimo, że popularność aplikacji mobilnych rośnie, wciąż jeszcze jest niewystarczająca aby znalazły one powszechne zastosowanie w promocji gospodarstw agroturystycznych.

\section{Literatura}

Badzińska E.: Mobilność, interaktywność i zaangażowanie użytkowników jako wyzwania współczesnej komunikacji w biznesie, „Zeszyty Naukowe Uniwersytetu Szczecińskiego”, 41(1)/2015. doi: 10.18276/pzfm.2015.41/1-02.

Borys M., Plechawska-Wójcik M.: Badanie użyteczności oraz dostępności interfejsu w aplikacjach mobilnych, „Nierówności Społeczne a Wzrost Gospodarczy”, 35/2013.

Brzostek-Pawłowska J.: Między Web 2.0 i 3.0: Mobilne systemy informacyjne z rozszerzonq rzeczywistościq, „Elektronika: konstrukcje, technologie, zastosowania”, 51(11)/2010.

Chabior B.: Rynek marketingu mobilnego, „Raport Interaktywnie.com: Marketing Mobilny”, 2016, za: https://goo.gl/s1ouo7, data dostępu: 05.09.2017.

Chochołowski B.: Za każda wersja systemu stoja potencjalni klienci. Bliska śmierć Windows Phone'a nie uprości rynku, „Raport Interaktywnie.com: Marketing Mobilny”, 2016, za: https://goo.gl/s1ouo7, data dostępu: 05.09.2017.

Gartner: Market Share: Final PCs, Ultramobiles and Mobile Phones, All Countries, 4Q16, za: https://goo.gl/19sJ8c, data dostępu: 24.09.2017.

Hew J.J., Lee V.H., Leong L.Y., Hew T.S., Ooi K.B.: The dawning of mobile tourism: what contributes to its system success? „International Journal of Mobile Communications”, 14(2)/2016. doi: 10.1504/IJMC.2016.075023.

Jaremen D.E., Michalska-Dudek I., Rapacz, A.: Wirtualizacja zachowań konsumentów na rynku turystycznym jako źródło wiedzy w podejmowaniu decyzji marketingowych, ,Studia i Prace WNEiZ US”, 43(2)/2016. doi: 10.18276/sip.2016.43/2-08.

Jasiulewicz A.: Aplikacje mobilne jako innowacja marketingowa, „Marketing i Rynek”, 8/2015.

Jasiulewicz A.: Aplikacje mobilne jako innowacyjne narzędzie marketingu mobilnego na rynku żywności, „Zeszyty Naukowe Uniwersytetu Szczecińskiego. Problemy Zarządzania, Finansów i Marketingu, Rola podmiotów rynkowych w kształtowaniu wizerunku organizacji i postrzeganiu wartości marki”, 41/2015.

Jasiulewicz A., Wiaderny M.: Aplikacje mobilne jako innowacyjne narzędzia promocji marki $w$ opinii konsumentów, „Logistyka”, 2/2015.

Kalecińska J.: Nowe technologie w branży turystycznej, AWF, Warszawa 2013, za: https://goo.gl/9f2URF data dostępu: 14.05.2017.

Kall J.: Branding na smartfonie. Komunikacja mobilna marki, Oficyna a Wolters Kluwer Business, Warszawa 2015.

Kall J.: Planowanie komunikacji mobilnej marki, „Nierówności Społeczne a Wzrost Gospodarczy”, 45/2016. doi: 10.15584/nsawg.2016.1.28.

Kall J.: Witryny i aplikacje mobilne w komunikacji marek odzieżowych, „Handel Wewnętrzny”, 2(367)/2017.

Kennedy-Eden H., Gretzel U.: A taxonomy of mobile applications in tourism, ,e-Review of Tourism Research", 10(2)/2012.

Kęprowska U.: Zastosowanie marketingu mobilnego w branży turystycznej, „Handel Wewnętrzny”, $6(353) / 2014$.

Kieżel M., Wiechoczek J.: Kierunki rozwoju mobilnej komunikacji marketingowej w usługach na przykładach usług bankowych i turystycznych, „Zeszyty Naukowe Uniwersytetu Szczecińskiego. Problemy Zarządzania, Finansów i Marketingu", 32/2013.

Kopecka-Piech K.: Mobilne media miejskie, „Studia Medioznawcze”, 3(50)/2012.

Kopecka-Piech K.: Aplikacje mobilne: innowacyjność, sytuacyjność $i$ personalizacja komunikacji marketingowej $i$ wizerunkowej, „Nowe Media. Studia i Rozprawy”, 4/2013. doi: 10.12775/NM.2013.001.

Król K.: Kalkulacja kosztów wykonania oraz promocji strony internetowej gospodarstwa agroturystycznego, „Acta Sci. Pol. Formatio Circumiectus”, 14(4)/2015. doi: 10.15576/ASP.FC/2015.14.4.41. 
Król K.: Globalne zmiany technologiczne i ich wplyw na promocję agroturystyki $w$ internecie, „Roczniki Naukowe Ekonomii Rolnictwa i Rozwoju Obszarów Wiejskich”, 103(3)/2016.

Król K., Bedla D.: Ocena wykorzystania technologii responsywności $w$ projektach witryn internetowych gospodarstw agroturystycznych, ,Problemy Drobnych Gospodarstw Rolnych - Problems of Small Agricultural Holdings", 3/2015.

Król K., Halva J.: Measuring efficiency of websites of agrotouristic farms from Poland and Slovakia/Pomiar efektywności witryn internetowych gospodarstw agroturystycznych z Polski $i$ Stowacji, „Economic and Regional Studies", 10(2)/2017.

Lysik Ł., Machura P.: Rola i znaczenie technologii mobilnych $w$ codziennym życiu człowieka XXI wieku, „Media i Społeczeństwo”, 4/2014.

Mękarski M.: Mystery shopping oraz shadowing jako metody badania kultury, „Roczniki Kulturoznawcze”, $5(1) / 2017$.

Olearnik J., Pasek K.: Innowacyjność w turystyce $i$ jej oddziaływanie promocyjne, „Rozprawy Naukowe Akademii Wychowania Fizycznego we Wrocławiu", 46/2014

Papińska-Kacperek J.B.: Miejskie aplikacje mobilne w turystyce kulturowej w Polsce, „Turystyka Kulturowa”, 2/2016.

Pawlicz A.: E-turystyka, Wydawnictwo Naukowe PWN, Warszawa 2012.

Pelc-Mieczkowska R.: Koncepcja pozyskania danych na potrzeby multimedialnego przewodnika mobilnego po szlakach turystycznych, ,Roczniki Geomatyki - Annals of Geomatics”, 13(1(67)/2015.

Piechota N.: Lokalizacyjna aplikacja mobilna jako narzędzie badań ruchu turystycznego w miastach, „Studia Oeconomica Posnaniensia", 2(1)/2014.

Piekarz K.: Trendy rozwojowe - potencjat i bariery, w: Raport IAB Polska: Perspektywy rozwojowe mobile online w Polsce 2015, 2015, za: https://goo.gl/NmSwsq data pobrania: 10.09.2017.

PwC: Technologie mobilne $w$ nowoczesnej Polsce - odpowiedzialny rozwój $i$ równe szanse, Polska Izba Informatyki i Telekomunikacji, 2016, za: https://goo.gl/QRHfSd, data pobrania: 10.09.2017.

Rasińska R., Siwiński W.: Aplikacje mobilne jako innowacyjne źródła informacji turystycznej dla studentów, „Rozprawy Naukowe Akademii Wychowania Fizycznego we Wrocławiu”, 50/2015.

Rohm A.J., Gao T., Sultan F., Pagani M.: Brand in hand: a cross-market investigation of consumer acceptance of mobile marketing, „Business Horizons”, 55(5)/2012. doi: 10.1016/j.bushor.2012.05.004.

Rudnicki M.: Wykorzystanie aplikacji mobilnej jako innowacyjnego kanału komunikacji przedsiębiorstw rynku turystycznego z konsumentami na przykładzie Kopalni Soli Wieliczka, „Prace Naukowe Uniwersytetu Ekonomicznego we Wrocławiu. Gospodarka turystyczna w regionie: wybrane problemy funkcjonowania regionów, gmin i przedsiębiorstw turystycznych", 303/2013.

Sadowska E.: Marketing mobilny a komunikacja marketingowa, „Studia Ekonomiczne”, 140/2013.

Shankar V., Balasubramanian S.: Mobile marketing: A synthesis and prognosis, „Journal of Interactive Marketing", 23(2)/2009. doi: 10.1016/j.intmar.2009.02.002.

Shankar V., Kleijnen M., Ramanathan S., Rizley R., Holland S., Morrissey S.: Mobile Shopper Marketing: Key Issues, Current Insights, and Future Research Avenues, „Journal of Interactive Marketing”, 34/2016. doi: 10.1016/j.intmar.2016.03.002.

Sznajder A.: Wplyw mobilnej technologii informacyjnej na działalność marketingowa przedsiębiorstw, „Gospodarka Narodowa”, 7/2013.

Talukder A.K., Yavagal R.R.: Mobile Computing: Technology Applications and Service Creation, McGrawHill Companies, New York 2007.

Watson C., McCarthy J., Rowley J.: Consumer attitudes towards mobile marketing in the smart phone era, „International Journal of Information Management”, 33(5)/2013. doi: 10.1016/j.ijinfomgt.2013.06.004.

\section{Abstract}

The aim of the paper was to evaluate opportunities and the rate of using websites and mobile applications by agrotouristic farms in presentation and promotion of provided services. The surveys were performed in three fields: responsiveness of the message as well as project and economic ones. 287 websites of agrotouristic farms were tested. The mobile applications for a model agrotouristic farm were created during the tests. Economic conditions of creating the mobile applications were tested by sending the requests for the proposal.

Not a single mobile website was noted in the set of surveyed websites. Also, none of the farms was providing a mobile application. The agrotouristic farms from the tested set were usually 
using the responsive websites. The workers of responded entities avoided in their answers the topic of performing a mobile application. Most of them suggested that due to practical (efficiency) and economic issues it would be more beneficial to promote a farm by means of the website adapted to mobile devices. In conclusion, it was proved that the prevalence of using mobile applications in promotion of agrotouristic farms is limited by the following barriers: usefulness, costs and also knowledge and skills.

Keywords: promotion of agrotourism, mobile technologies, mobile websites, responsiveness of the message, mobile devices

Informacje o autorze:

dr inż. Karol Król

Uniwersytet Rolniczy im. Hugona Kołłątaja w Krakowie

Wydział Inżynierii Środowiska i Geodezji

Katedra Gospodarki Przestrzennej i Architektury Krajobrazu

Al. Mickiewicza 24/28, 30-059 Kraków

e-mail:k.krol@onet.com.pl 